\title{
Effects of Dietary Flammulina velutipes Mycelium on Physico-chemical Properties and Nutritional Components of Chicken Meat
}

\author{
Sang-Bum Lee', Ji-Hee Kim', Su-Youn Jeong ${ }^{1}$, Tao Wang ${ }^{2}$, Seong-Keun Cho', Teak-Soon Shin', \\ Han-Seok Kang', Youn-Chil Kim³ ${ }^{3}$, Seon-Ku Kim ${ }^{1}$ and Hong-Gu Lee ${ }^{2}$. \\ ${ }^{1}$ College of Natural Resource and Life Science, Pusan National University, Gyeongnam 627-706, Korea \\ ${ }^{2}$ College of Animal Bioscience and Technology, Konkuk University, Seoul 143-701, Korea \\ ${ }^{3}$ Green Filed EM Bio Feed Co. Ltd, Yangsan, Gyeongnam 626-856, Korea
}

Received May 13, 2013 /Revised July 9, 2013 /Accepted July 25, 2013

\begin{abstract}
The purpose of this study was to evaluate the effects of dietary Flammulina velutipes mycelium (FVM) on physico-chemical properties and nutritional components of chicken meat. Ninety-six broiler chicks (HanHyup No. 3, Korea) were divided into four groups: control (basal diet), T1 (supplemented with $1 \% \mathrm{FVM}), \mathrm{T} 2(3 \%)$, and T3 $(5 \%)$. Broiler chicks in each group were slaughtered at 7 weeks of age, and their breast and thigh meat were collected. Lightness $\left(\mathrm{L}^{*}\right)$ and yellowness $\left(\mathrm{b}^{*}\right)$ in the T2 and T3 groups were higher than in the control group $(p<0.05)$. The loss of breast meat during cooking was increased in the T1, T2, and T3 groups, and the water-holding capacity of the breast meat was also decreased in these three groups $(p<0.05)$. The water-soluble protein solubility was lower in the T1, T2, and T3 groups than in the control group $(p<0.05)$, but the salt-soluble protein solubility in these three groups was higher than that in the control group $(p<0.05)$. The crude fat content of the breast meat was decreased and that of the thigh meat was increased as the level of FVM was increased ( $p<0.05)$. The unsaturated fatty acid content of the breast meat was higher in the T2 and T3 groups than in the control group $(p<0.05)$. The free amino acid content was high in the T1, T2, and T3 groups compared to the control. In conclusion, these results showed that feeding with 3\% and 5\% FVM increased the $\mathrm{L}$ and $\mathrm{b}$ values in thigh meat, improved the salt-soluble protein solubility, and increased the content of unsaturated fatty acids and free amino acids.
\end{abstract}

Key words : Flammulina velutipes mycelium (FVM), chicken meat, physico-chemical properties, fatty acid, free amino acid

\section{서 론}

현재 우리나라의 축산업은 수입자유화로 인해 다량 유입되 는 외국 축산물을 대비하여 가격적인 면에 있어서 경쟁력을 확보하는 것이 중요하다. 더불어 국민 소득 및 문화수준의 향 상으로 높아지는 소비자들의 요구를 맞추기 위하여 해결해야 할 많은 과제를 안고 있다. 이를 위해서는 첫째, 사료 원료의 90\% 이상이 수입되고 있는 문제점을 해결하기 위하여 기존사 료의 대체 물질을 개발하고, 둘째로 수입 또는 기존 축산물보 다 품질이 뛰어난 고품질 축산물을 개발해야 하며, 셋째는 건 강에 대한 관심도가 높은 소비자를 위한 기능성 축산물 개발 하고, 마지막 넷째로 소비자들의 식품안정성을 충족시킬 수 있는 위생적인 축산물을 생산하여야 한다.

\section{*Corresponding author}

Tel : +82-2-450-0523, Fax : +82-2-455-1044

E-mail : hglee66@konkuk.ac.kr

This is an Open-Access article distributed under the terms of the Creative Commons Attribution Non-Commercial License (http://creativecommons.org/licenses/by-nc/3.0) which permits unrestricted non-commercial use, distribution, and reproduction in any medium, provided the original work is properly cited.
육계는 다른 가축에 비해 사료효율이 높고, 성장속도가 빠 른 가축으로서 이들로부터 생산된 닭고기는 가격이 저렴한 반면, 영양가가 높다. 특히 다른 가축의 고기보다 살코기 중에 포화 지방산 함량이 적고, 불포화 지방산 함량이 높아 건강식 품으로서의 가치를 인정받고 있다[8]. 최근 육계의 고급육 생 산을 위하여 다양한 약용식물 자원이 사료첨가제로 사용되고 있으며[29, 37], 그 중에서 국내 부존자원 및 농산 부산물들 또한 각종 시험을 통하여 좋은 효과를 나타내었다. Kang 등 [27]은 눈꽃동충하초균주(Paecilomyces japanica) 접종사료를 육 계에게 급여한 결과 가슴살 및 대퇴부살에서 항균효과 및 항 암효과가 있는 cordycepin 성분 함량이 유의성 있게 높게 나타 났다고 보고하였으며, Lee 등[31]은 육계에 팽이버섯 균사체 의 사료 내 첨가 급여는 맹장 내 Salmonella 균 수와 계분 내 암모니아가스 발생량이 현저하게 감소되었다고 하였다.

팽이버섯(Flammulina velutipes)은 담자균류의 주름버섯목 (Agaricales) 송이과(Tricholomataceae)에 속하는 균으로 야생에 서 팽나무, 뽕나무, 사시나무 등의 활엽수 줄기나 뿌리를 분해 하는 백색 부후균의 하나로서[16], 오래 전부터 인공재배에 의 해 생산되어 왔다. 일반적으로 버섯은 일반식품에 비하여 무 농약 천연식품으로서 다른 농작물에서 합성이 적은 라이신 
등 필수아미노산이나 무기질 등이 비교적 다양하게 함유되어 있으며, 버섯 성분 중에는 단백질, 아미노산 등이 풍부할 뿐만 아니라 $\beta$-glucan, 비타민 및 미량원소 등이 함유하고 있다[23, 58]. 특히 버섯은 산화 방지제 성분인 tocopherol [25]과 ascorbic acid 그리고 carotenoids [20], phenolic 성분[4], organic acids [51] 등 기능성 성분이 많은 천연자원으로 알려져 있다. 그 중 carotenoid는 암[55], 심장혈관질환[24] 등 위험요소를 감소시킨다.

팽이버섯은 전국 24 개 농가에서 재배되어 연간 43,098 ton 의 팽이버섯을 생산하고 있다[33]. 하지만 재배된 팽이버섯을 수확하여 식용으로 가공되는 과정에서 뿌리부분의 균사체 (mycelium)가 다량으로 폐기되고 있으므로 이러한 폐기자원 을 사료화하는 것은 부존자원의 효율적 활용 및 환경오염의 방지 측면에서 중요하다고 판단된다.

본 연구에서는 폐기 균사체의 사료화를 위한 기초자료를 제시코자 폐기 처분되는 팽이버섯 균사체(Flammulina velutipes Mycelium)를 육계에 첨가 급여하여 닭고기의 이화학적 특성과 영양성분에 미치는 영향을 조사하기 위한 실험을 수행 하였다.

\section{재료 및 방법}

\section{공시동물 및 시험장소}

본 연구에서는 경상남도 밀양 무안면 소재인 한신 부화장에 서 생산된 1일령 토종 닭(HanHyup No.3) 96수를 임의로 선발 하여 시험에 공시하였고, 부산대학교 생명자원과학대학 부속 농장 가금사 평사에서 7주간 사육하였다.

\section{Flammulina velutipes mycelium (FVM) 및 기초사료}

본 연구에 이용한 $\mathrm{FVM}$ 은 지역의 버섯농장에서 생산된 팽 이버섯으로부터 나온 FVM을 상온에서 건조시킨 후 사료분쇄 기(J-NCM, Jisico, Korea)를 이용하여 Sieve mesh를 20 mesh 로 분말을 만들어 사용하였다. 기초사료는 육계전용사료로 4 주령 이전은 육계전기사료(가루)를 급여하였고, 이후는 육계 후기사료(크럼블)를 급여하였다. 기초사료 배합표는 Table 1 에 나타내었다.

\section{실험설계}

1 일령 토종 닭 96 수를 처리구 당 8수씩 3반복으로 완전임의 배치하였으며, 각 개체의 무게는 처리구 및 반복간 비슷하게 조절하여 배치하였다. 각 처리구별 사료급여 기준은 1) C (기 초사료), 2) T1 (기초사료 $+1 \% \mathrm{FVM}$ ), 3) T2 (기초사료 + $3 \%$ $\mathrm{FVM})$, 4) T3 (기초사료 $+5 \% \mathrm{FVM})$ 로 급여시켰으며, 기초사료 $1 \mathrm{~kg}$ 에 대한 $\mathrm{FVM}$ 첨가량 $(\mathrm{g})$ 은 $\mathrm{C} 0.0, \mathrm{~T} 110.0, \mathrm{~T} 230.0, \mathrm{~T} 3$ 50.0 이다.
Table 1. Ingredients and chemical composition of basal diets

(Calculated values)

\begin{tabular}{lcc}
\hline Ingredients & Starter $(\%)^{1)}$ & Finisher $(\%)^{2)}$ \\
\hline Corn grain (CHI) & 51.46 & 55.24 \\
Mixed grain (wheat) & 6.00 & 5.00 \\
Soybean M/L LOC & 27.34 & 25.24 \\
Corn gluten M/L & 5.00 & 5.00 \\
Animal fat & 5.00 & 5.00 \\
Salt dehydrated & 0.25 & 0.25 \\
DCP (18.5/23.0) & 2.12 & 1.96 \\
Limestone (1 mm) & 0.94 & 0.92 \\
LIQ-Methionine (HYMETBI+) & 0.33 & 0.29 \\
The others & 1.56 & 1.10 \\
\hline Total & 100.00 & 100.00 \\
\hline Chemical composition & & \\
ME (kcal/kg) & $3,050.00$ & $3,100.00$ \\
Crude protein (\%) & 19.50 & 19.50 \\
Crude fat (\%) & 4.50 & 5.50 \\
Crude Ash (\%) & 8.00 & 8.00 \\
Crude fiber (\%) & 6.00 & 6.00 \\
Ca (\%) & 0.80 & 0.85 \\
Available P (\%) & 1.50 & 1.50 \\
\hline
\end{tabular}

The others
${ }^{1)}$ Starer-Declazulil, 0.05; Neomycin 77G (neocin), 0.024;
Avilamycine, 0.4; L-Lysine (A, A-4), 0.274; LIQ-Cholin Chloride
$50 \%, 0.08$; VIT Premix (Poultry-3), 0.15; Minpremix (Poultry-3),
0.15; Avizyme-1500, 0.03; Smuos, 0.15; Oxizory-D, 0.03;
Pastron, 0.05; Odor kare, 0.004; ALL-Mix, 0.15.
${ }^{2}$ Finisher- Maduramicin (10 g), 0.05; Avilamycine, 0.0.24;
L-Lysine (A, A-4), 0.168; LIQ-Cholin Chloride 50\%, 0.07; VIT
Premix (Poultry-3), 0.15; Min Premix (Poultry-3), 0.15;
Avizyme-1500, 0.03; Smuos, 0.15; Promax (Berberine), 0.05;
Oxizory-D, 0.03; BZF-Galicin, 0.05; Odor kare, 0.004; Pig-koll,
0.02; All-Mix, 0.15.

\section{사양관리}

1 일령 육계병아리를 사육실로 이동하여 4 개 시험구에 3 분 할하여 배치하고, 입추 후 1 주일간은 예비기로서 대조구와 처 리구간의 구분 없이 육계전기사료만을 급여하였다. 2주령부 터 4 주령까지는 실험설계에 따라 육계전기 사료를 급여하였 고, 5 주령에서 7 주령까지는 육계후기사료를 급여하였다. 7 주 령 이후 도축하여 이화학적 특성을 조사하기 위해서 가슴근육 과 다리근육을 채취하였다. 시험기간 동안 처리 별 사료와 물 은 자유 채식하도록 하였으며, 24시간 점등하였다.

\section{조사 항목 및 실험방법}

\section{일반성분 분석}

$\mathrm{FVM}$ 의 수분, 조단백질, 조지방, 조섬유, 조회분, 칼슘 및 인 분석은 $\mathrm{AOAC}[1]$ 방법에 의하여 실시하였다. $\mathrm{FVM}$ 의 화학 성분(\%)은 수분 10.52 , 조단백질 12.23 , 조지방 6.24 , 조섬유 13.69 , 조섬유 16.92 , 칼슘 2.21 , 인 1.68 이다. 


\section{육색}

육색은 가슴(천흥근과 상오구근)과 정강이(대퇴2, 4 두근과 비복근)의 단면을 chroma meter (JP/CR 300, Minolta, Japan) 를 사용하여 측정하였다. 측정값은 명도(lightness)를 나타내 는 $\mathrm{L}^{*}$ 값, 적도색(redness)를 나타내는 $\mathrm{a}^{*}$ 값, 황색도(yellowness) 를 나타내는 $b^{*}$ 값의 hunter값을 9 회 반복 고루 측정하여 평균 값을 사용하였다. 표준 값은 $\mathrm{y}$ 값(92.40), $\mathrm{x}$ 값(0.3136), $\mathrm{y}$ 값 (0.3196)의 백색타일 calibration plate를 사용하였다.

\section{가열감량 및 총 수분함량}

가열 감량(cooking loss, \%)은 시료를 일정하게 절단하여 철망에 넣고, 시료가 담긴 철망은 원심분리 튜브에 넣은 후 laboratory film (PM-996, Menasha, USA)으로 원심분리 튜브 상단을 밀봉하였다. 밀봉한 원심분리튜브를 $70^{\circ} \mathrm{C}$ 의 항온수조 에 30 분간 가열하고 꺼내어 10 분간 냉각 후 $1,300 \mathrm{rpm}$ 에서 10 분간 원심분리를 하고 무게를 측정하였다. 가열감량은 다음 의 공식에 의하여 산출하였다.

가열 감량 $(\%)=\frac{\text { 가열 전 시료중량-가열 후 시료중량 }}{\text { 가열 전 시료중량 }} \times 100$

총 수분함량(total water, \%)은 유리샬레의 무게를 잰 후 시 료를 일정하게 절단하여 유리샬레에 올려놓고 무게를 재었다. 그런 후 dry oven (LDO-080N, 대한랩테크, Korea)에서 $102^{\circ} \mathrm{C}$ 로 하여 16 시간 동안 건조시킨 후 2,1 시간, 30,15 분마다 측정 하여 변화가 없을 때의 수치를 측정하였다. 지문이 묻지 않도 록 비닐장갑을 끼고 이동하였으며, 미세저울(XB220A, Precisa, swiss)에서 0.000 단위까지 측정하였다. 총 수분함량 은 다음의 공식에 의하여 산출하였다.

총 수분함량 $(\mathrm{W}(\%))=\frac{(\mathrm{c}-\mathrm{d})}{\mathrm{b}} \times 100$

*유리샬레무게 $=\mathrm{a}$, 시료무게 $=\mathrm{b}, \mathrm{a}+\mathrm{b}=\mathrm{c}$, 항량시 무게 $=\mathrm{d}$

\section{보수력}

보수력(water-holding capacity, \%)은 가열 감량과 동일한 방법으로 측정되었다. 보수력은 다음의 공식에 의하여 산출하 였다.

$$
\begin{aligned}
& \text { 보수력 }(\%)=\frac{\text { 총 수분함량 }(\mathrm{W})-\text { 유리수분함량 }(\mathrm{F})}{\text { 총 수분함량 }(\mathrm{W})} \times 100 \\
& \text { 유리수분 }(\mathrm{F}(\%))=\frac{\text { 원심분리 전 무게 }- \text { 원심분리 후 무게 }}{\text { 시료×지방계수 }} \times 100 \\
& \text { 지방계수 }(\%)=1-\frac{\text { 지방 }(\%)}{100} \times 100
\end{aligned}
$$

\section{수용성 및 염용성 단백질 용해성}

단백질의 용해성은 Saffle와 Galbreath [40]의 방법에 따라 서 실험하였다. 수용성 단백질 추출은 시료 $2 \mathrm{~g}$ 에 증류수 12 $\mathrm{ml}$ 를 넣고, homogenizer (T25, 동양과학, Korea)를 사용하여 $10,000 \mathrm{rpm}$ 에서 1 분간 균질화하였다. 이것을 원심분리기 (KR/Union 5KR, Hanil, Korea)에서 2,450 rpm, rotor code 1 , 온도 $15^{\circ} \mathrm{C}$ 에서 centrifuging하여 상등액을 취해 비커에 넣었 다. 남은 잔사에 증류수 $12 \mathrm{ml}$ 를 넣어 다시 centrifuging 한 뒤 상등액을 취하여 비커에 모은 후 그 추출액을 가지고 시험 관에 Biuret 시약을 이용하여 비율 3(Biuret 시약): 2(추출액)로 섞었다. 섞은 용액은 자외-가시선 분광광도계(UV-9100, HUMAN, USA)를 이용하여 $540 \mathrm{~nm}$ 에서 Biuret법[17]으로 측 정하였다. 염용성 단백질 추출은 수용성 단백 질 추출을 하고 남은 잔사에 동일한 방법으로 증류수 대신 $\mathrm{NaCl}$ 을 $12 \mathrm{ml}$ 넣었 다. 그런 후 두 번 상층액을 걸러 비커에 모은 후 그 추출액을 가지고 Biuret 시약과 혼합하고, 자외-가시선 분광광도계를 이 용하여 $540 \mathrm{~nm}$ 에서 측정하였다. 용해된 단백질 량은 $\mathrm{mg} / \mathrm{g}$ 로 나타내었다.

\section{조지방 함량 및 지방산 조성}

조지방 함량 및 지방산 조성 그리고 아미노산 함량에 사용 된 시료는 일반성분분석과 동일한 도축방법, 저장방법으로 $-21^{\circ} \mathrm{C}$ 냉동고에 저장한 후 실험 시 해동하여 사용하였다. 조지 방은 Folch법[22]을 이용하여 함량을 구하였다. 세절한 시료 (A) $3 \mathrm{~g}$ (오차허용기준: $3.00 \pm 0.03 \mathrm{~g}$ )을 $50 \mathrm{ml}$ conical tube에 넣고 Folch I 인 혼합 solvent (chloroform: methanol(2:1))를 $15 \mathrm{ml}$ 를 첨가한 다음 Homogenizer를 이용하여 2,500 rpm에 서 3 분간 균질화시켰다. homogenizer에 묻은 지질 조각을 Folch I $5 \mathrm{ml}$ 를 이용하여 $50 \mathrm{ml}$ conical tube에 모은 후 균질화 된 시료에서 조지방의 추출액이 완전히 빠져 나오도록 하기 위해 2시간 동안 항온실에 방치하였다. 방치 후 추출액을 100 $\mathrm{ml}$ 메스실린더에 설치된 여과지(Whatman No 1.)에 여과시켰 고, $50 \mathrm{ml}$ conical tube에 남아있는 지질 조각도 포함시키기 위해 Folch I $5 \mathrm{ml}$ 을 $50 \mathrm{ml}$ conical tube에 넣고 세척시켜 함께 여과시켰다. 여과지에 다시 Folch I 를 골고루 $5 \mathrm{ml}$ 넣어 조지방 추출을 유도한 후 메스실린더에 $0.88 \% \mathrm{NaCl}$ 를 총 여액 의 $1 / 3$ 정도 첨가하여 shaking시켜 상층(methanol, 증류수, $\mathrm{NaCl}$ )과 하층(조지방, chloroform)을 분리시켰다. 분리된 하 층의 높이(B)를 측정한 후 aspirator (VE11, JEOTECH, Korea) 를 이용하여 연결된 모세관으로 상층액을 버리고 하층(lipid layer)만을 취하였다. lipid layer에서 $10 \mathrm{ml}(\mathrm{C})$ 를 dish에 넣고 dry oven $60^{\circ} \mathrm{C}$ 이상에서 30 분 동안 chloroform을 완전히 건조 시켰다. 건조시킨 dish무게에서 dish무게를 빼 조지방 무게 (D)를 구했다. 조지방은 다음의 공식에 의하여 산출하였다.

\section{조지방 $(\%)=(\mathrm{D} \times \mathrm{B}) / \mathrm{C} / \mathrm{A} \times 100$}

닭고기 중 지방산 분석은 Folch법을 이용한 조지방 시료를 methylene chloride $1 \mathrm{ml}$ 로 지방을 녹인 후 $0.5 \mathrm{~N} \mathrm{NaOH}$ (in methanol)을 $1 \mathrm{ml}$ 첨가하여 heating block하에 $90^{\circ} \mathrm{C}$ 에서 10 분 
간 saponification시켰다. 종료 후 10 분간 냉각하고, $\mathrm{BF}_{3}$ (boron trifloride methanol solution)를 $1 \mathrm{ml}$ 첨가시키고, 다시 $90^{\circ} \mathrm{C}$ 에 서 10 분간 methylation시켰다. Methylation이 끝난 glass tube 에 hexane $3 \mathrm{ml}$ 와 증류수 $8 \mathrm{ml}$ 를 넣고 섞은 후 원심분리기에 서 원심분리(1,000 rpm, $10 \mathrm{~min}$ )를 해주었다. $2 \mathrm{ml}$ test tube를 준비해서 $\mathrm{Na}_{2} \mathrm{SO}_{4}$ 를 소량 넣고, 상층(지방산 추출물)에서 $1.5 \sim 2$ $\mathrm{ml}$ 채취하여 수분을 제거한 후 상층을 유리 syringe에 filtering $\left(0.2 \mu \mathrm{m}\right.$ filter)시키면서 GC분석용 vial병에 넣어 $-21^{\circ} \mathrm{C}$ 에 서 보관하였다. GC 분석 시 vial병에서 $1 \mu \mathrm{ll}$ 를 $10 \mathrm{\mu l}$ syringe에 취하여 GC에 주입 후 지방산을 분리 정성, 정량 하였다. 이때 GC 분석은 Agilent 6890 (Agilent Technologies, Inc., USA)를 사용하였으며, MSD (mass selective detector)는 Agilent 5973 를 이용하였다. Column은 HP-5MS ( $30 \mathrm{~m} \times 0.25 \mathrm{~mm} \times 0.25 \mu \mathrm{m})$ 을 사용하였으며, oven온도는 $170^{\circ} \mathrm{C}$ 에서 3 분간 정치시켰으며, 분당 $15^{\circ} \mathrm{C}$ 씩 증가시켜 $280^{\circ} \mathrm{C}$ 에서 7 분간 정치시켰다. 주입 및 접촉온도 조건은 $260^{\circ} \mathrm{C}$ 로 설정하였으며, 이온화 전압은 $70 \mathrm{eV}$, 그리고 이동상 가스는 $\mathrm{He}$ (통과율: $1 \mathrm{ml} / \mathrm{min}$ )를 사용하였다.

\section{아미노산 함량}

세절한 시료 $10 \mathrm{~g}$ 을 증류수 $50 \mathrm{ml}$ 와 혼합하여 homogenizer 에서 약 $1,400 \mathrm{rpm}$ 으로 5 분간 균질화시킨 다음 slurry를 centrifuging $(4,000 \mathrm{rpm} / 20 \mathrm{~min})$ 시켜 whatman No. 2로 여과시 켰다. 여과액에 $12 \%$ TCA solution을 증류수와 같은 동량 50 $\mathrm{ml}$ 을 첨가시켜 침전시킨 다음 냉건소에서 1 시간 침전 시켰다. 침전된 것을 균형을 바르게 하기 위해 centrifuging $(4,000$ $\mathrm{rpm} / 20 \mathrm{~min}$ )시킨 후 상등액을 분별깔때기에 넣고, 상등액에 ethyl ether $50 \mathrm{ml}$ 를 가하여 TCA와 lipid를 제거하기 위해 3회 반복하여 하층을 재 추출하였다. 이렇게 회수한 하층을 evaporator $\left(40^{\circ} \mathrm{C}\right)$ 로 혹시나 남아있을 $12 \%$ TCA solution 과 ethyl ether를 감압 건조하여 증발시킨 후 농축액 $3 \mathrm{ml}$ 와 $0.2 \mathrm{M}$ Lithium citrate loading buffer (pH 2.2) $7 \mathrm{ml}$ 를 희석시켜 10 $\mathrm{ml}$ 를 만든 후 membrane filter $(0.45 \mu \mathrm{m})$ 로 여과하여 자동 아 미노산 분석기(Biochrom 30, Pharmacia Biotech., UK)에 40 $\mu 1$ 를 주입하여 분석하였다. Buffer는 Lithium citrate buffer를 이용하였으며, 온도범위는 $40 ~ 145^{\circ} \mathrm{C}$ 로 설정하였으며, column 은 20 $99^{\circ} \mathrm{C}$ 로 설 정하여 사용하였다.

\section{통계 분석}

시험 및 분석 등을 통해서 얻어진 성적들은 SAS package [41]의 ANOVA Procedure로 분산분석을 실시하였고, Duncan's New Multiple Range Test를 이용하여 유의성 검정 을 실시하였다.

\section{결과 및 고찰}

\section{육색}

$\mathrm{FVM}$ 을 육계사료에 첨가 급여 시 닭고기의 육색의 변화는 Table 2에서 보는 바와 같다. 명도를 나타내는 $\mathrm{L}^{*}$ 값은 $\mathrm{FVM}$ 의 첨가수준을 증가시킬수록 가슴근육에서 높아지는 경향을 보 였으며, T2와 T3에서는 대조구에 비하여 유의적으로 높아졌 다( $p<0.05)$. 다리근육에서는 $\mathrm{FVM}$ 의 $3 \%$ 첨가 수준인 $\mathrm{T} 2$ 에서 대조구와 비교하여 유의하게 높아졌으나( $p<0.05), \mathrm{T} 3$ 에서는 오히려 대조구보다 낮아졌다( $p<0.05)$. 닭고기의 밝고 어두움 을 나타내는 명도의 값은 육질 평가에 영향을 주는 요인 중에 하나이다[18]. 닭처럼 스트레스를 잘 받는 가금류에서는 사양 관리, 운송 및 계류 때 생성되는 열 스트레스(heat stress)로 인하여 이상육(PSE: pale, soft, exudative)이 발생되며, 이때 낮은 $\mathrm{pH}$ 와 낮은 명도로 인하여 창백한 현상을 나타나게 되는 데[3], 이것이 육색 뿐만 아니라 보수성 및 연도에도 영향을 준다고 하였다[36]. 버섯의 letinan, grifolan과 같은 polysaccharide, polysaccharide peptide, protein kinase substrate-peptide와 같은 다당류-펩타이드 복합체 및 fungal immunomodulatory protein과 같은 단백질은 혈압 조절, 바이러 스 증식 억제 및 면역력 증강 $[35,49,50]$ 등의 작용을 하는 것으로 알려져 있다. 그러므로 본 연구에서 $\mathrm{FVM}$ 의 육계 사료 내 첨가는 스트레스 감소와 관련하여 육계의 가슴근육의 명도 를 개선시키는 것으로 나타났다.

적색도를 나타내는 a* 값의 가슴근육에서는 FVM의 첨가 급여수준을 증가시킬수록 낮아지는 경향을 나타냈으며, $5 \%$ 첨가인 $\mathrm{T} 3$ 에서는 대조구 및 다른 첨가 수준에 비하여 유의적 으로 낮아졌다 $(p<0.05)$. 하지만 다리근육에서는 대조구에 비 해 $\mathrm{FVM}$ 의 $1 \%$ 첨가와 $5 \%$ 첨가에서는 높아졌으나 $3 \%$ 첨가에 서는 낮아져 일정한 경향을 나타내지 못하였다.

Table 2. Effects of dietary dehydrated Flammulina velutipes mycelium on meat color of breast and thigh in broiler chicks

\begin{tabular}{ccccccc}
\hline \multirow{2}{*}{ Treatment $^{1)}$} & \multicolumn{3}{c}{ Breast } & \multicolumn{3}{c}{ Thigh } \\
\cline { 2 - 7 } & $\mathrm{L}^{*}$ & $\mathrm{a}^{*}$ & $\mathrm{~b}^{*}$ & $\mathrm{~L}^{*}$ & $\mathrm{a}^{*}$ & $\mathrm{~b}^{*}$ \\
\hline C & $49.08 \pm 0.14^{\mathrm{c}}$ & $4.02 \pm 0.04^{\mathrm{a}}$ & $9.75 \pm 0.03^{\mathrm{b}}$ & $53.11 \pm 0.15^{\mathrm{b}}$ & $10.03 \pm 0.39^{\mathrm{c}}$ & $11.62 \pm 0.15^{\mathrm{b}}$ \\
T1 & $49.15 \pm 0.32^{\mathrm{c}}$ & $3.89 \pm 0.17^{\mathrm{a}}$ & $9.86 \pm 0.07^{\mathrm{b}}$ & $52.50 \pm 0.33^{\mathrm{b}}$ & $11.53 \pm 0.19^{\mathrm{b}}$ & $11.77 \pm 0.10^{\mathrm{ab}}$ \\
T2 & $50.26 \pm 0.37^{\mathrm{b}}$ & $3.77 \pm 0.19^{\mathrm{a}}$ & $10.10 \pm 0.28^{\mathrm{ab}}$ & $54.63 \pm 0.07^{\mathrm{a}}$ & $7.59 \pm 0.17^{\mathrm{d}}$ & $11.87 \pm 0.21^{\mathrm{ab}}$ \\
T3 & $51.40 \pm 0.37^{\mathrm{a}}$ & $2.69 \pm 0.00^{\mathrm{b}}$ & $10.53 \pm 0.20^{\mathrm{a}}$ & $51.01 \pm 0.66^{\mathrm{c}}$ & $14.19 \pm 0.39^{\mathrm{a}}$ & $12.21 \pm 0.10^{\mathrm{a}}$ \\
\hline Plood SE & 0.316 & 0.169 & 0.117 & 0.423 & 0.733 & 0.090 \\
\hline
\end{tabular}

$\overline{a, b, c, d}$ : Values (Mean \pm SE) within columns with no common superscript differ significantly $(p<0.05)$

${ }^{1)} \mathrm{C}$, none; $\mathrm{T} 1,1 \%$ Flammulina velutipes, $\mathrm{T} 2,3 \%$ Flammulina velutipes, $\mathrm{T} 3,5 \%$ Flammulina velutipes 
황색도를 나타내는 $b^{*}$ 값은 가슴과 다리근육에서 FVM의 첨가 수준을 증가시킬수록 모든 처리구간에 높아지는 경향을 나타내었다 $(p<0.05)$. 닭의 경우 $\beta$-carotene과 xanthophyll 계 통의 색소물질을 함유하고 있는 옥수수 위주의 사료를 섭취함 으로써 피부에 착색되어 육색은 황색계통의 빛을 띄는 것으로 알려져 있다[7]. 하지만 Kang 등[26]의 논문에 의하면 lutein이 라는 천연색소 물질이 많은 무청분말과 시금치분말의 급여에 의 해서도 다른 처리구에 비해 황색도가 유의하게 높게 나타났다고 보고하였으며, Chae 등[15]은 현미 수준이 증가할수록 황색도( $\left.\mathrm{b}^{*}\right)$ 가 유의적으로 감소하였는데, 이것은 현미에는 옥수수 안에 함유 된 xanthophyll이라는 색소가 상대적으로 적기 때문이라고 평하 였다. 이렇듯 첨가되는 물질의 색소성분에 따라서 육색이 변할 수 있는데, 버섯에 포함되어 있는 carotenoid류(carotene, xanthophyll)에 의해 육색에 영향을 준 것으로 사료된다.

가금류는 carotenoid류를 합성하는 능력이 없어 사료 또는 첨가물을 통해서만 축적된다고 하며[2], 특히 xanthophyll은 산란계에 있어서 달걀 난황색을 짙게 하는 물질로 알려져 있 어서[6], 버섯의 첨가는 산란계 산업에 있어서 달걀 난황색에 도 영향을 줄 것으로 예상되며, 버섯은 quenching singlet oxygen [9], trapping free radical 등의 작용을 가지므로 지질 과산 화를 저해함으로 효과적인 항산화제 역할도 할 수 있을 것으 로 사료된다.

\section{가열감량, 총 수분함량 및 보수력 측정}

$\mathrm{FVM}$ 을 육계에 첨가 급여 후 생산된 닭고기에 대한 가열감 량, 총 수분함량 및 보수력은 Table 3에 나타내었다.

가슴근육의 가열감량은 대조구(7.49\%)에 비하여, $\mathrm{T} 1$ (14.57\%), T2 (16.14\%), T3 (12.14\%)로 처리구에서 유의적으로 높았다( $\propto \times 0.05)$. 반면 다리근육에는 $\mathrm{FVM}$ 을 첨가 급여한 경우 낮아지는 경향을 나타내었으나 처리 간에 유의적 차이는 없었 다. 일반적으로 가열감량과 전단력이 낮을수록 관능특성 중 연도와 보수성이 우수하다 하였다[10]. 하지만 본 연구에서 $\mathrm{FVM}$ 의 첨가 급여에 의해 육계의 가슴근육 가열감량이 높아 져 연도와 보수성에 부정적인 영향을 줄 것으로 사료된다.

총 수분함량은 가슴과 다리근육 모두에서 처리간의 유의적
차이를 보이지 않았다. 보수력은 가슴근육에서 대조구 $(89.96 \%), \mathrm{T} 1(80.24 \%), \mathrm{T} 2(78.25 \%), \mathrm{T} 3(83.78 \%)$ 로 처리간의 유의적 차이를 나타내었고( $p<0.05), \mathrm{FVM}$ 을 첨가 급여한 경우 낮은 결과를 보였다. 그러나 다리근육에서는 처리 간에 유의 적인 차이는 보이지 않았다. 가열감량은 단백 질 변성에 의하 여 변화하며, 보수력에도 영향을 미친다는 Winger와 Fennema [53]의 결과와 가열감량은 다즙성과 연도에 부(-)의 상관관계가 있다고 보고한 Serra 등[43]의 주장과 동일하게 본 연구에서 또한 가열감량이 높은 처리구에서 보수력이 낮아지 는 결과를 보였다. 보수력은 육의 외관과 조리 및 제품 제조 시 큰 영향을 주는 요소이며[39], 외부의 충격에도 유출되지 않는 내재된 수분의 양으로서, 고기의 연도 및 조직감 그리고 맛과 연관이 있다[52]. 그러므로 본 연구의 결과 육계에 FVM 의 사료 내 1 5\% 첨가는 가슴근육의 가열감량 및 보수성에 부정적인 영향을 줄 것으로 사료된다.

\section{수용성 및 염용성 단백질 용해성}

$\mathrm{FVM}$ 을 육계에 첨가 급여 시 가슴과 다리근육 내 수용성 단백질 및 염용성 단백질의 용해성은 Table 4 에서 보는 바와 같다.

가슴근육에서 수용성단백질의 용해성은 FVM 첨가 급여수 준이 높을수록 유의적으로 낮아졌고( $p<0.05)$, 다리근육에서도 낮아졌다 $(p<0.05)$. 염용성단백질의 용해성은 가슴근육에서 대 조구 $(0.45 \mathrm{mg} / \mathrm{g})$ 에 비하여 T1 $(0.58 \mathrm{mg} / \mathrm{g})$ 과 T2 $(0.78 \mathrm{mg} / \mathrm{g})$ 에서 유의적으로 증가하였고 $(p<0.05)$, 다리근육에서 또한 $1 \%$ 의 FVM을 급여한 T1 $(0.37 \mathrm{mg} / \mathrm{g})$ 에서는 대조구 $(0.40 \mathrm{mg} / \mathrm{g})$ 와 비슷하였으나, T2 $(0.54 \mathrm{mg} / \mathrm{g})$ 와 T3 $(0.65 \mathrm{mg} / \mathrm{g})$ 에서 유의 적으로 높아졌다 $(p<0.05)$. 염용성 단백질은 대부분 myosin과 actomyosin으로 구성된 근원섬유단백질로 열에 의해 단백질 이 응집된 후 상호 교차반응으로 인해 gel화되는 특징을 가지 고 있으며[21], 가공공정 중 수분과의 결합력을 유지하면서 최 종 제품의 물성증진을 유도하여 식육가공제품의 조직감을 증 진시키는 것으로 알려져 있다[30]. 그러므로 육계의 육질에 있 어서 $\mathrm{FVM}$ 의 첨가 급여는 $1 \%$ 와 $3 \%$ 는 가슴근육, 그리고 $3 \%$ 와 $5 \%$ 에서는 다리근육을 가공하였을 때에 더 우수한 품질의 육

Table 3. Effects of dietary dehydrated Flammulina velutipes mycelium on the cooking $\operatorname{loss}^{1}$, total water ${ }^{2}$, water-holding capacity ${ }^{3}$ of breast and thigh in broiler chicks (\%)

\begin{tabular}{ccccccc}
\hline \multirow{2}{*}{ Treatment $^{1)}$} & \multicolumn{3}{c}{ Breast } & \multicolumn{3}{c}{ Thigh } \\
\cline { 2 - 7 } & C.L $^{1}$ & T.W & W.H.C & C.L $^{1}$ & T.W $^{2}$ & W.H.C $^{3}$ \\
\hline C & $7.49 \pm 0.14^{\text {d }}$ & $74.58 \pm 0.37$ & $89.96 \pm 0.17^{\mathrm{a}}$ & $17.37 \pm 1.85$ & $76.59 \pm 0.23$ & $77.66 \pm 2.46$ \\
T1 & $14.57 \pm 0.07^{\mathrm{b}}$ & $73.64 \pm 0.18$ & $80.24 \pm 0.14^{\mathrm{c}}$ & $16.02 \pm 0.71$ & $76.32 \pm 0.93$ & $78.88 \pm 1.17$ \\
T2 & $16.14 \pm 0.33^{\mathrm{a}}$ & $74.19 \pm 0.13$ & $78.25 \pm 0.46^{\mathrm{d}}$ & $17.06 \pm 0.42$ & $77.46 \pm 0.38$ & $78.06 \pm 0.47$ \\
T3 & $12.14 \pm 0.31^{\mathrm{c}}$ & $74.59 \pm 0.39$ & $83.78 \pm 0.48^{\mathrm{b}}$ & $15.56 \pm 0.89$ & $75.88 \pm 0.36$ & $79.41 \pm 1.14$ \\
\hline Plood SE & 0.991 & 0.169 & 1.350 & 0.521 & 0.290 & 0.670
\end{tabular}

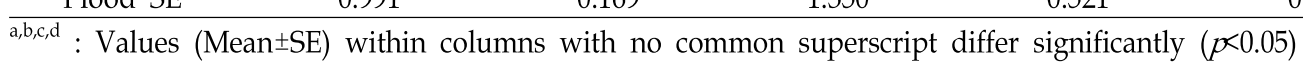

${ }^{1)} \mathrm{C}$, none; $\mathrm{T} 1,1 \%$ Flammulina velutipes, $\mathrm{T} 2,3 \%$ Flammulina velutipes, $\mathrm{T} 3,5 \%$ Flammulina velutipes 
Table 6. Effects of dietary dehydrated Flammulina velutipes mycelium on fatty acid composition in breast of broiler chicks (\%)

\begin{tabular}{|c|c|c|c|c|}
\hline \multirow{2}{*}{ Fatty acid } & \multicolumn{4}{|c|}{ Treatment ${ }^{1)}$} \\
\hline & $\mathrm{C}$ & $\mathrm{T} 1$ & $\mathrm{~T} 2$ & T3 \\
\hline C14:0 & $1.45 \pm 0.01^{\mathrm{a}}$ & $1.40 \pm 0.01^{b}$ & $1.42 \pm 0.01^{\mathrm{ab}}$ & $1.40 \pm 0.01^{b}$ \\
\hline $\mathrm{C} 16: 0$ & $23.48 \pm 0.21$ & $23.63 \pm 0.08$ & $23.48 \pm 0.35$ & $23.29 \pm 0.37$ \\
\hline $\mathrm{C} 16: 1$ & $5.07 \pm 0.04^{\mathrm{b}}$ & $5.20 \pm 0.08^{b}$ & $5.62 \pm 0.12^{\mathrm{a}}$ & $5.39 \pm 0.17^{\mathrm{ab}}$ \\
\hline C17:0 & $0.16 \pm 0.01^{b}$ & $0.25 \pm 0.01^{\mathrm{a}}$ & $0.24 \pm 0.02^{\mathrm{a}}$ & $0.22 \pm 0.02^{\mathrm{a}}$ \\
\hline $\mathrm{C} 18: 0$ & $7.95 \pm 0.50^{\mathrm{a}}$ & $6.82 \pm 0.27^{b}$ & $6.13 \pm 0.21^{b}$ & $5.85 \pm 0.16^{b}$ \\
\hline C18:1 (n-9) & $44.21 \pm 0.22$ & $45.31 \pm 0.50$ & $45.07 \pm 0.66$ & $45.19 \pm 0.36$ \\
\hline C18:2 (n-6) & $13.90 \pm 0.12^{\mathrm{ab}}$ & $13.31 \pm 0.14^{b}$ & $13.72 \pm 0.13^{b}$ & $14.34 \pm 0.28^{\mathrm{a}}$ \\
\hline C18:3 (n-3) & $0.47 \pm 0.01^{b}$ & $0.52 \pm 0.02^{\mathrm{ab}}$ & $0.53 \pm 0.02^{\mathrm{a}}$ & $0.57 \pm 0.01^{\mathrm{a}}$ \\
\hline C20:4 (n-6) & $2.57 \pm 0.03$ & $2.61 \pm 0.01$ & $2.84 \pm 0.18$ & $2.77 \pm 0.09$ \\
\hline $\mathrm{C} 22: 5(\mathrm{n}-3)$ & $0.41 \pm 0.03^{b}$ & $0.45 \pm 0.00^{\mathrm{ab}}$ & $0.44 \pm 0.01^{\mathrm{ab}}$ & $0.47 \pm 0.02^{\mathrm{a}}$ \\
\hline $\mathrm{C} 22: 6(\mathrm{n}-3)$ & $0.53 \pm 0.01$ & $0.50 \pm 0.02$ & $0.51 \pm 0.02$ & $0.51 \pm 0.01$ \\
\hline $\mathrm{SFA}^{1}$ & $32.84 \pm 0.30^{\mathrm{a}}$ & $32.10 \pm 0.34^{\text {ab }}$ & $31.27 \pm 0.40^{\text {bc }}$ & $30.76 \pm 0.51^{\mathrm{c}}$ \\
\hline USFA $^{2}$ & $67.16 \pm 0.30^{c}$ & $67.90 \pm 0.34^{\text {bc }}$ & $68.73 \pm 0.40^{\mathrm{ab}}$ & $69.24 \pm 0.51^{\mathrm{a}}$ \\
\hline USFA/SFA & $2.05 \pm 0.03^{c}$ & $2.12 \pm 0.03^{b c}$ & $2.20 \pm 0.04^{\mathrm{ab}}$ & $2.25 \pm 0.06^{\mathrm{a}}$ \\
\hline$n-6 / n-3$ & $11.68 \pm 0.12^{\mathrm{a}}$ & $10.83 \pm 0.08^{b}$ & $11.19 \pm 0.24^{\mathrm{b}}$ & $11.04 \pm 0.09^{b}$ \\
\hline
\end{tabular}

Values are means of 3 chicken meat.

C14:0 (myristic acid), C16:0 (palmitic acid), C16:1 (palmitoleic acid), C17:0 (magaric acid), C18:0 (stearic acid), C18:1 (OA: oleic acid, n-9), C18:2 (LA: linoleic acid, n-6), C18:3 (ALA: alpha - Linolenic acid, n-3), C20:4 (AA: arachidonic acid, 0-6), C22:5 (DPA: Docosapentaenoic acid, n-3), C22:6 (DHA: Docosahexaenoic acid, n-3)

${ }^{1}$ USFA (Unsaturated fatty acid) : C16:1, C18:1, C18:2, C18:3, C20:4, C22:5, C22-6

${ }^{2}$ SFA (Saturated fatty acid) : C14:0, C16:0, C17:0, C18:0

n-6/n-3: C18:2, C20:4 / (C18:3, C22:5, C22:6)

${ }^{1)} \mathrm{C}$, none; $\mathrm{T} 1,1 \%$ Flammulina velutipes, $\mathrm{T} 2$, 3\% Flammulina velutipes, $\mathrm{T} 3$, 5\% Flammulina velutipes

Table 7. Effects of dietary dehydrated Flammulina velutipes mycelium on fatty acid composition in thigh of broiler chicks (\%)

\begin{tabular}{|c|c|c|c|c|}
\hline \multirow{2}{*}{ Fatty acid } & \multicolumn{4}{|c|}{ Treatment ${ }^{1)}$} \\
\hline & $\mathrm{C}$ & $\mathrm{T} 1$ & $\mathrm{~T} 2$ & $\mathrm{~T} 3$ \\
\hline C14:0 & $0.77 \pm 0.08^{\mathrm{bc}}$ & $0.69 \pm 0.01^{\mathrm{c}}$ & $0.90 \pm 0.03^{\mathrm{ab}}$ & $1.03 \pm 0.03^{\mathrm{a}}$ \\
\hline $\mathrm{C} 16: 0$ & $23.43 \pm 0.15$ & $23.63 \pm 0.27$ & $23.48 \pm 0.08$ & $23.30 \pm 0.32$ \\
\hline $\mathrm{C} 16: 1$ & $6.00 \pm 0.12^{\mathrm{a}}$ & $5.94 \pm 0.15^{\mathrm{a}}$ & $5.50 \pm 0.06^{\mathrm{b}}$ & $5.47 \pm 0.14^{\mathrm{b}}$ \\
\hline $\mathrm{C} 17: 0$ & $0.29 \pm 0.02^{\mathrm{a}}$ & $0.21 \pm 0.00^{\mathrm{b}}$ & $0.21 \pm 0.00^{\mathrm{b}}$ & $0.21 \pm 0.01^{b}$ \\
\hline C18:0 & $7.02 \pm 0.20$ & $6.88 \pm 0.19$ & $7.03 \pm 0.31$ & $6.53 \pm 0.17$ \\
\hline C18:1 (n-9) & $43.65 \pm 0.48$ & $43.97 \pm 0.31$ & $44.29 \pm 0.42$ & $43.47 \pm 0.18$ \\
\hline C18:2 (n-6) & $14.64 \pm 0.28$ & $15.11 \pm 0.21$ & $15.26 \pm 0.28$ & $15.26 \pm 0.14$ \\
\hline C18:3 (n-3) & $0.50 \pm 0.02^{b}$ & $0.56 \pm 0.01^{\mathrm{a}}$ & $0.53 \pm 0.02^{\mathrm{ab}}$ & $0.57 \pm 0.01^{\mathrm{a}}$ \\
\hline C20:4 (n-6) & $2.69 \pm 0.05$ & $2.71 \pm 0.01$ & $2.72 \pm 0.01$ & $2.72 \pm 0.01$ \\
\hline $\mathrm{C} 22: 5$ (n-3) & $0.47 \pm 0.01$ & $0.52 \pm 0.02$ & $0.50 \pm 0.03$ & $0.53 \pm 0.02$ \\
\hline $\mathrm{C} 22: 6(\mathrm{n}-3)$ & $0.54 \pm 0.02^{\mathrm{a}}$ & $0.49 \pm 0.02^{\mathrm{ab}}$ & $0.54 \pm 0.02^{\mathrm{a}}$ & $0.46 \pm 0.01^{\mathrm{b}}$ \\
\hline $\mathrm{SFA}^{1}$ & $31.51 \pm 0.41$ & $31.41 \pm 0.31$ & $31.62 \pm 0.24$ & $31.07 \pm 0.33$ \\
\hline USFA $^{2}$ & $68.49 \pm 0.41$ & $69.30 \pm 0.31$ & $69.34 \pm 0.24$ & $68.48 \pm 0.33$ \\
\hline USFA/SFA & $2.17 \pm 0.04$ & $2.21 \pm 0.04$ & $2.19 \pm 0.03$ & $2.20 \pm 0.03$ \\
\hline$n-6 / n-3$ & $11.48 \pm 0.12$ & $11.35 \pm 0.08$ & $11.45 \pm 0.30$ & $11.53 \pm 0.17$ \\
\hline
\end{tabular}

Values are means of 3 chicken meat.

C14:0 (myristic acid), C16:0 (palmitic acid), C16:1 (palmitoleic acid), C17:0 (magaric acid), C18:0 (stearic acid), C18:1 (OA: oleic acid, n-9), C18:2 (LA: linoleic acid, n-6), C18:3 (ALA: alpha - Linolenic acid, n-3), C20:4 (AA: arachidonic acid, 0-6), C22:5 (DPA: Docosapentaenoic acid, n-3), C22:6 (DHA: Docosahexaenoic acid, n-3)

${ }^{1}$ USFA (Unsaturated fatty acid) : C16:1, C18:1, C18:2, C18:3, C20:4, C22:5, C22-6

${ }^{2} \mathrm{SFA}$ (Saturated fatty acid) : C14:0, C16:0, C17:0, C18:0

n-6/n-3: C18:2, C20:4 / (C18:3, C22:5, C22:6)

${ }^{1)} \mathrm{C}$, none; $\mathrm{T} 1,1 \%$ Flammulina velutipes, $\mathrm{T} 2$, 3\% Flammulina velutipes, $\mathrm{T} 3$, 5\% Flammulina velutipes 


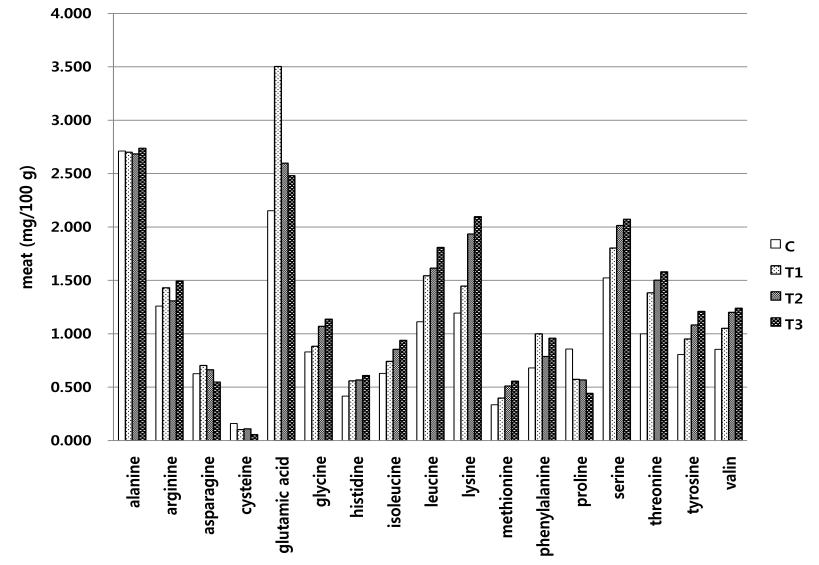

Fig. 1. Content of free amino acid in breast meat of broiler chicks fed dehydrated Flammulina velutipes mycelium. C, none; T1, 1\% Flammulina velutipes, T2, 3\% Flammulina velutipes, T3, 5\% Flammulina velutipes.

화지방산을 증가시키며 $(p<0.05)$, 오메가 -6 지방산의 증가 없 이 alpha-Linolenic acid (C18:3, ALA, n-3)와 docosahexaenoic acid (C22:6, DHA, n-3)의 오메가 -3 지방산이 증가하여 지방 산 조성이 개선된 것으로 나타났다. 그러므로 이처럼 $\mathrm{FVM}$ 의 첨가급여에 의해 오메가-3 지방산 중 다가 불포화지방산인 $\mathrm{EPA}, \mathrm{ALA}$ 및 $\mathrm{DHA}$ 가 증가된 육계가 생산되면 최근 건강을 생각하는 다수의 소비자들에게 긍정적인 영향을 줄 것으로 사료된다.

\section{유리 아미노산 함량}

$\mathrm{FVM}$ 을 육계에게 첨가 급여 시 닭고기 중의 유리 아미노산 함량은 Fig. 1과 2에서 나타내었다. Fig. 1에서 가슴근육 100 $\mathrm{g}$ 중의 총 유리아미노산 함량은 $\mathrm{C}, \mathrm{T} 1, \mathrm{~T} 2, \mathrm{~T} 3$ 에서 각각 17.21, 20.24, 21.06, $22.33 \mathrm{mg}$ 으로 나타났으며, 특히 glutamic acid는 $\mathrm{FVM} 1 \%$ 첨가 급여인 $\mathrm{T} 1$ 에서 대조구보다 상당 수준 높아졌다. 전체적으로 볼 때 $\mathrm{FVM}$ 첨가 급여는 유리아미노산 함량을 증 가시켰는데, arginine, glycine, histidine, isoleucine, leucine, lysine, methionine, phenylalanine, serine, threonine, valine 등 거의 대부분의 주요 아미노산 등이 FVM 첨가 급여 수준이 높아질수록 높게 나타났다. Chae 등[15]에 의하면 육계의 가슴 근육 methionine함량은 $0.57 \%$ 라고 하였으며, glutamic acid함 량은 $2.85 \%$ 라고 하였는데, 본 연구에서 대조구는 함량이 다소 적었으나, 처리구는 유사한 수치를 나타내었다. 특히 가슴근 육 T1의 glutamic acid는 국내 FCT [19]의 $3.82 \%$ 와 Chae 등 [14]의 $3.63 \%$ 와 거의 유사한 결과를 나타내었다. 다리근육 100 $\mathrm{g}$ 중의 유리아미노산 함량은 $\mathrm{C}, \mathrm{T} 1, \mathrm{~T} 2, \mathrm{~T} 3$ 에서 각각 19.85, $21.45,23.55,24.30 \mathrm{mg}$ 으로 나타났으며, 유리아미노산의 함량 분포는 Fig. 2와 같이 다리근육에서 또한 가슴근육과 함께 glutamic acid의 함량이 현저하게 높았으며, lysine, methionine, serine, threonine 함량도 증가하였다.

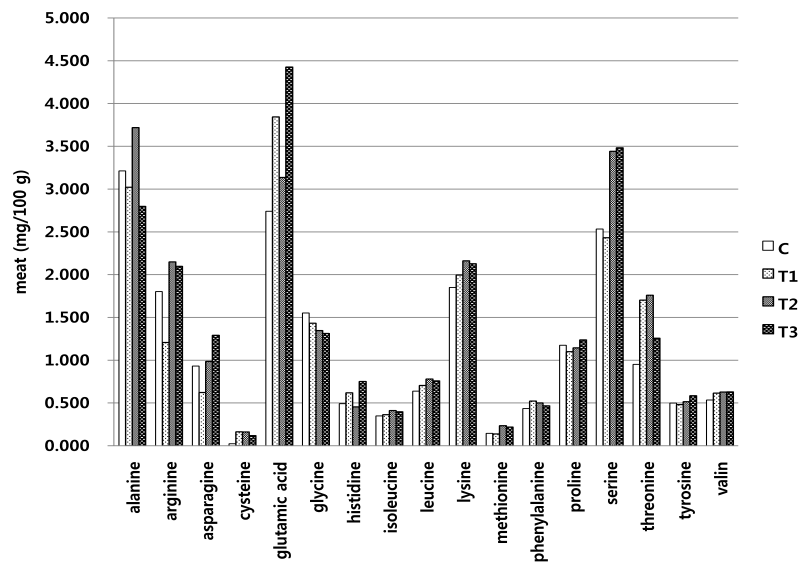

Fig. 2. Content of free amino acid in thigh meat of broiler chicks fed dehydrated Flammulina velutipes mycelium. C, none; T1, 1\% Flammulina velutipes, T2, 3\% Flammulina velutipes, $\mathrm{T} 3$, 5\% Flammulina velutipes.

유리아미노산은 단백질 합성은 물론 신경전달물질과 같은 중요한 생물학적 기능에도 관여하고, 면역계를 강화하고 항산 화작용 등을 하는 물질로 알려져 있으며[13], McCain [32]의 논문에 의하면 유리아미노산은 숙성기간 동안 펩타이드와 유 리아미노산이 생산되어 식육의 맛과도 관련이 있다고 하였다. 닭고기에서 특히 methionine은 단맛에 관여하고[14], glutamic acid는 짠맛, 그리고 phenylalanine과 isoleucine은 신맛에 관여한다[12]. 아미노산은 펩티드, 아민, 당, 유기산, 헥산 등의 비휘발성 화합물들과 함께 가열할 때 마이야르 반응(아미노산 과 환원당)이 작용하여 영양뿐만 아니라 고기의 풍미에도 영 향을 준다[11, 44]. 그러므로 본 연구는 FVM을 사료에 첨가 급여함으로써 육계의 가슴, 다리근육의 아미노산의 함량을 증 진시킴으로써 풍미향상에 효과가 있을 것으로 사료된다.

\section{감사의 글}

본 연구는 농림식품부의 농업기술개발사업(No. 610005-033-SB310) 지원에 의하여 수행되었으며, 이에 감사드립니다.

\section{References}

1. AOAC. 2004. Official Analytical Chemists. Washington DC. USA.

2. Balnave, D. and Bird, J. N. 1996. Relative efficiencies of yellow carotenoids for egg yolk pigmentation. Asian-aus ${ }^{-}$ tralas J Anim Sci 9, 515.

3. Barbut, S., Sosnicki, A. A., Lonergan, S. M., Knapp, T., Ciobanu, D.C., Gatcliffe, L. J., Huff-Lonergan, E. and Wilson, E. W. 2008. Progress in reducing the pale, soft and exudative (PSE) problem in pork and poultry meat. Meat Sci 79, 46-63.

4. Barros, L., Dueñas, M., Ferreira, I. C. F. R., Baptista, P. and 
Santos-Buelga, C. 2009. Phenolic acids determination by HPLC-DAD-ESI/MS in sixteen different Portuguese wild mushrooms species. Food Chem Toxicol 47, 1076-1079.

5. Betti, M., Perez, T. I., Zuidhof, M. J. and Renema, R. A. 2009. Omega-3-enriched broiler meat: 3. Fatty acid distribution between triacylglycerol and phospholipid classes. Poult Sci 88, 1740-1754.

6. Brambila, S. J., Pino, J. A. and Mendoza, C. 1963. Studies with a natural source of xanthophylls for the pigmentation of egg yolks and skin of poultry. Poult Sci 42, 295.

7. Branellec, J. C. 1985. La pigmentation du poulet de chair. Aliscope 85, 1-13.

8. Bourre, J. M. 2005. Where to find omega-3-fatty acids and how feeding animals with diet enriched in omega-3-fatty acids to increase nutritional value derived products for human: What is actually useful? J Nutr Health Aging 9, 232-242.

9. Burton, G.W. 1989. Antioxidant action of carotenoids. J Nutr 119, 109-111.

10. Caine, W. R., Aalbus, J., Bcst, D. R., Dugan, M. E. and Jeremia, L. E. 2003. Relationship of texture profile analysis and Warner-Bratzler shcar force with sensory characteristics of beef rib stcaks. Meat Sci 64, 333-339.

11. Cambero, M. I., Seuss, I. and Honikel, K. O. 1992. Flavor compounds of beef broth as affected by cooking temperature. J Food Sci. 57, 1285-1290.

12. Careri, M., Mangia, A., Barbieri, G., Bolzoni, L., Virgili, R. and Parolari, G. 1993. Sensory property relationship to chemical date of Italian type dry-cured ham. J Food Sci 58, 968-972.

13. Chae, H. S., Choi, H. C., Na, J. C., Kim, M. J., Kang, H. K., Kim, D. W., Kim, J. H., Jo, S. H., Kang, G. H. and Seo, O. S. 2012. Effect of Raising Periods on Amino Acids and Fatty Acids Properties of Chicken Meat. Korean J Poult SCi 39, 77-85.

14. Chae, H. S., Cho, S. H., Park, B. Y., Yoo, Y. M., Kim, J. H., Ahn, C. N., Lee, J. M., Kim, Y. K., Yun, S. G. and Choi, Y. I. 2002. Comparison of chemical composition in different portions of domestic broiler meat. Korean J Poult Sci 29, 51-57.

15. Chae, H. S., Hwangbo, J., Ahn, C. N., Yoo, Y. M., Cho, S. H., Lee, J. M. and Choi, Y. I. 2004. Effect of dietary brown rice on the carcass and meat quality of broiler chicken. Korean J Poult Sci 31, 165-170.

16. Chai, J. K. 2001. Re-cultivation of Flammulina velutipes from media used for cultivation of Flammulina velutipes. Mushroom 5, 113-124.

17. Cooper, T. G. 1977. Biuret protein determination. In "The tools of biochemistry". John wiley \& Sons New York, 51.

18. Faustman, C. and Cassens, R. G. 1990. The biochemical basis for discoloration in fresh meat: a review. J Muscle Food 1, 217-243.

19. FCT. 2006. Food Composition Table. Rural Resources Development Institute. National Institute of Agriculture Science and Technology, RDA.

20. Ferreira, I. C. F. R., Barros, L. and Abreu, R. M. V. 2009. Antioxidants in wild mushrooms. Curr Med Chem
16,1543-1560.

21. Foegeding, E. A. 1988. Thermally induced changes in muscle proteins. Food Technol 42, 58-64.

22. Folch, J., Lees, M. and Sloane-Stanley, G. H. 1957. A simple method for the isolation and purification of total lipids from animal tissues. J Biol Chem 226, 497-507.

23. Furlani, R. P. Z. and Godoy, H. T. 2007. Vitamins B1 and B2 contains in cultivated mushrooms. Food Chem 106, 816-819.

24. Gaziano, J. M. and Hennekens, C. H. 1993. The role of beta-carotene in the prevention of cardiovascular disease. Ann NY Acad Sci 691, 148.

25. Heleno, S. A., Barros, L., Sousa, M. J., Martins, A. and Ferreira, I. C. F. R. 2010. Tocopherols composition of Portuguese wild mushrooms with antioxidant capacity. Food Chem 119, 1443-1450.

26. Kang, G. H., Kim, S. H., Kim, Kim, J. H., Kang, H. K., Kim, D. W., Cho, S. H., Seong, P. N., Park, B. Y., Ham, J. S. and Kim, D. H. 2011. Effects of dietary radish green and spinach on meat quality and lutein accumulation in broiler tissue. Korean J Food Sci Anim Resour 31, 86-91.

27. Kang, H. S., Son, J. H., Lee, K. W., Kim, S. K., Cho, B. W., Shin, T. S. and Jeon, H. Y. 2003. Effects of inoculated diet with Paecilomyces japonica on broiler performance. Korean $J$ Poult Sci 30, 49-54.

28. Kim, B. K., Jung, D. J., Hwang, E. G. and Choi, C. B. 2012. Effects of Supplementation of Macsumsuk and Herb Resources on Growth Performances and Meat Quality of Broiler Chickens. Korean J Food Sci Anim Resour 32, 512-519.

29. Kim, Y. J. 2013. Effects of dietary supplementation of yacon (Polymnia sonchifdia) by-products on performance and physico-chemical properties of chicken thigh meat. Korean J Poult Sci 40, 1-9.

30. Lee, H. C. and Chin, K. B. 2009. Effect of transglutaminase, acorn, and mungbean powder on quality characteristics of low fat/ salt pork model sausages. Korean J Food Sci Anim Resour 29, 374-381.

31. Lee, S. B., Choi, Y. H., Cho, S. K., Shin, T. S., Cho, B. W., Kang, H. S., Kim, K. K., Kim, S. K. and Lee, H. G. 2012. Effects of dietary Flammulina velutipes mycelium on broiler chick performance, pathogenic bacterial conunts in caecal contents and amount of $\mathrm{NH}_{3}$ in excreta. Korean J Anim Sci Technol 54, 341-347.

32. McCain, G. R., Blumer, T. N., Craig, H. B. and Steel, R. G. 1968. Free amino acids in ham muscle during successive aging periods and their relation to flavor. J Food Sci 33, 142-146.

33. Ministry for Food, Agriculture, Forestry and Fisheries. 2011. 2011 Industrial Crops actual output. http://library. mifaff.go.kr/skyblueimage/694.pdf.

34. Narciso-Gaytan, C., Shin, D., Sams, A. R., Keeton, J. T., Miller, R. K., Smith, S. B. and Sanchez-Plata, M. X. 2011. Lipid oxidation stability of omega-3- and conjugated linoleic acid-enriched sous vide chicken meat. Poult Sci 90, 473-480.

35. Ohmori, T., Tamura, A., Wakaiki, A., Kawanishi, G., Tsuru, S., Yadomae, T. and Nomoto, K. 1988. Dissociation of a glu- 
ca fraction (CO-1) from protein-bound polysaccharide of Cordyceps ophioglossoides and analysis of its antitumor effect. Chem Pharm Bull 36, 4512-4518.

36. Owens, C. M., Hirschler, E. M., Mckee, S. R. and Martinez-Dawson, R. 2000. The characterization and incidence of pale, soft, exudative SAS (1999) SAS/STAT software for PC. Release 6.11 SAS Institute, Cary, NC, USA.

37. Park, C. I. and Kim, Y. J. 2012. Effects of dietary supplementation of mulberry leaves powder on chicken meat quality stored during cold storage. Korean J Food Sci Anim Resour 32, 184-189.

38. Park, S. J. and Yoo, S. O. 1999. Effects of supplementation of Chinese medicine refuse on performance and physiology in broiler chicks. Korean J Poult Sci 26, 195-201.

39. Roseiro, L. C., Santana, C. and Melo, R. S. 1994. Muscle pH60 colour $(\mathrm{L}, \mathrm{a}, \mathrm{b})$ and water holding capacity and the influence of post mortem meat temperature. Meat Sci 38, 353.

40. Saffle, R. L. and Galbreaty, J. W. G. 1964. Quantitative determination of salt-soluble protein in various types of meat. Food tech 18, 1943.

41. SAS program Package. 2008. SAS/STAT. Software for PC, SAS/STAT User's Guide: Statistics. SAS Institute. Inc., Cary, NC.

42. Schreiner, M., Hulan, H. W., Razzazi-Fazeli, E., Bohm, J. B. and Moreira, R. G. 2005. Effect of different sources of dietary omega-3 fatty acids on general performance and fatty acid profiles of thigh, breast, liver and portal blood of broilers. J Sci Food Agric 85, 219-226.

43. Serra, X., Guerrero, L., Guardia, M, D., Gil, M., Sanude, C., Panea, B., Campo, M. M., Olleta, J. L., Carcia-Cachan, M. D., Piedrafita, J. and Oliver, M. A. 2008. Eating quality of young bulls from three Spanish beef breed-production systems and its relationships with chemical and instrumental meat quality. Meat Sci 79, 98-104.

44. Shahidi, F., Rubin, L. J. and D'Souza, L. A. 1996. Meat flavor volatiles: A review of composition, techniques of analysis and sensory evaluation. CRC Crit Rev Food Sci Nutr 24, 141-243.

45. Shin, D. 2010. Effect of conjugated linoleic acid or oleic acid addition on fatty acid composition profiles of poultry meat. Ph.D. Dissertation, Texas A\&M University at College Station, TX USA.

46. Shin, D., Narciso-Gaytan, C., Park, J. H., Smith, S. B., Sanchez-Plata, M. X. and Ruiz-Feria, C. A. 2011. Dietary combination of the effects of conjugated linoleic acid and flaxseed or fish oil on the deposition of linoleic and arachidonic acid in poultry meat. Poult Sci 90, 1340-1347.

47. Shin, D. K., Choi, S. H., Cho, Y. M. and Park, J. H. 2012. Omega-3 and -9 fatty acid combination effects on broiler chicks to produce chicks with high in omega-3 polyunsaturated fatty acid. Korean J Poult Sci 39, 1-8.

48. Smiderle, F. R., Carbonero, E. R., Mellinger, C. G., Sassaki, G. L., Gorin Philip, A. J. and Iacomini, M. 2006. Structural characterization of a polysaccharide and a $\beta$-glucan isolated from the edible mushroom Flammulinavelutipes. Phytochemistry 67, 2189-2196.

49. Supper, C. M. and Paul, W. E. 1987. Interferon and B cell stimulatory factor-1 reciprocally regulated $\mathrm{Ig}$ isotype production. Science 236, 944-947.

50. Tsunda, A. and Ishida, N. 1970. A mushroom extracts as an interferon inducer. Ann NY Acad Sci 173, 719-726.

51. Valentão, P., Lopes, G., Valente, M., Barbosa, P., Andrade, P. B., Silva, B. M., Baptista, P. and Seabra, R. M. 2005. Quantification of nine organic acids in wild mushrooms. $J$ Agric Food Chem 53, 3626-3630.

52. Wierbicki, E. and Deanherage, F. E. 1958. Determination of water holding capacity of fresh meat. J Agric Food Chem 6, 389-394.

53. Winger, R. T. and Fennema, O. 1976. Tenderness and water holding properties of beef muscle as influenced by freezing and subsequent storage at $-3^{\circ} \mathrm{C}$ or $15^{\circ} \mathrm{C}$. J Food Sci 41 , 1433-1438.

54. Youn, B. S., Nam, K. T., Chang, K. M., Hwang, S. G. and Choe, I. S. 2005. Effects of wood vinegar addition for meat quality improvement of old layer. Korean J Poult Sci 32, 101-106.

55. Ziegler, R. 1991. Vegetables, fruits, and carotenoids and the risk of cancer. Am J Clin Nutri 53(suppl), 251S. 


\section{초록 : 팽이버섯 균사체의 급여가 닭고기의 이화학적 특성과 영양성분에 미치는 영향}

이상범 ${ }^{1} \cdot$ 김지희 ${ }^{1} \cdot$ 정수연 ${ }^{1} \cdot$ 왕도 ${ }^{2} \cdot$ 조성근 $^{1} \cdot$ 신택순 $^{1} \cdot$ 강한석 $^{1} \cdot$ 김윤칠 $^{3} \cdot$ 김선구 $^{1} \cdot$ 이홍구 ${ }^{2} \star$

( ${ }^{1}$ 부산대학교 생명자원과학대학, ${ }^{2}$ 건국대학교 동물자원학과, ${ }^{3}$ (주푸른들 $\mathrm{EM}$ 사료)

본 연구는 FVM이 닭고기의 이화학적 특성과 영양성분에 미치는 영향을 조사하기 위하여 수행되었다. 지역의 버섯재배 농장에서 FVM을 수거하여 건조과정을 거친 다음 분쇄하여 사용하였다. 부화 후 1 주령의 육계 병아리 96 수를 4 개 그룹으로 나누어 대조구(C)는 기초사료만 급여하였고, 시험 1 구(T1)는 기초사료에 FVM $1 \%$ 를, 시험 2 구(T2)는 FVM 3\%를, 시험 3구(T3)는 FVM 5\%를 6주 동안 급여하였다. 7주령에 도계한 다음 가슴근육과 대퇴근

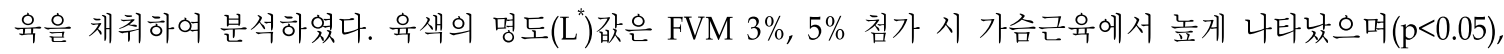
다리근육에서는 $3 \%$ 에서 높게 나타났다 $(p \times 0.05)$. 황색도 $\left(\mathrm{b}^{*}\right)$ 는 $\mathrm{FVM}$ 첨가수준이 증가될수록 가슴, 다리근육에서 높게 나타났다( $p<0.05)$. 모든 $\mathrm{FVM}$ 첨가 수준에서 가슴근육의 가열감량은 높아졌고 $(p<0.05)$, 보수력은 낮아졌으나 $(\beta \times 0.05)$, 다리근육에서는 차이가 없었다. 그리고 총 수분함량에서는 가슴, 다리근육 모두 대조구 및 처리구간의 영향이 없었다. 수용성 단백질의 용해성은 FVM 첨가 수준이 증가될수록 가슴근육과 다리근육에서 대조구에 비 하여 낮아졌고( $p<0.05)$, 염용성 단백질의 용해성은 가슴근육에서는 $1 \%$ 와 $3 \%$, 다리근육에서는 $3 \%$ 와 $5 \%$ 에서 대조 구에 비하여 유의하게 높아졌다( $p<0.05)$. 가슴근육의 조지방 함량은 FVM 첨가수준이 증가될수록 낮아진 반면 $(p<0.05)$, 다리근육의 조지방 함량은 높아졌다 $(p<0.05)$. 지방산 조성은 $\mathrm{FVM}$ 을 $3 \%$ 와 $5 \%$ 를 첨가할 경우 가슴근육 의 포화 지방산 함량을 대조구와 비교하여 유의하게 낮추고 $(p<0.05)$, 불포화 지방산의 함량을 유의하게 높였다 $(p<0.05)$. 아미노산 함량은 가슴근육(glutamic acid, glycine, histidine, isoleucine, leucine, lysine, methionine, phenylalanine, serine, threonine, tyrosine, valine)에서는 $\mathrm{FVM}$ 의 첨가수준이 증가할수록 높아졌으며, 다리근육 (glutamic acid, lysine, methionine, serine, threonine)은 FVM 처리구에서 대조구보다 높아지는 경향을 보였다. 이상의 결과를 종합해볼 때 $\mathrm{FVM}$ 의 $3 \%$ 와 $5 \%$ 첨가급여는 육계에 있어서 명도와 황색도, 염용성 단백질 용해성, 포화지방산 및 불포화 지방산 함량, 오메가-6에 대한 오메가-3 비율, 유리아미노산함량을 개선시킬 수 있을 것으 로 사료된다. 